\title{
Brain-derived Neurotrophic Factor (BDNF) Prevents the Degeneration of Medial Septal Cholinergic Neurons following Fimbria Transection
}

\author{
Joanne K. Morse, ${ }^{1}$ Stanley J. Wiegand, ${ }^{1}$ Keith Anderson, ${ }^{1}$ Yimin You, ${ }^{1}$ Ning Cai,, Josette Carnahan, ${ }^{2}$ James \\ Miller, ${ }^{2}$ Peter S. DiStefano, ${ }^{1}$ C. Anthony Altar, ${ }^{1}$ Ronald M. Lindsay, ${ }^{1}$ and Ralph F. Alderson' \\ ${ }^{1}$ Regeneron Pharmaceuticals Inc., Tarrytown, New York, 10591-6707, and '2Amgen Inc., Thousand Oaks, California 91320- \\ 1789
}

Brain-derived neurotrophic factor (BDNF), a member of the neurotrophin family, supports the survival of developing basal forebrain cholinergic neurons in vitro and is retrogradely transported by cholinergic neurons of the medial septum and diagonal band following intrahippocampal injections in vivo. To substantiate a potential role for BDNF in the maintenance of forebrain cholinergic neurons in the adult brain, we assessed the ability of BDNF to sustain the phenotype of medial septal cholinergic neurons following a unllateral transection of the fimbria. BDNF, NGF, or vehicle solutions were infused continuously in adult female rats either into the lateral ventricle (intracerebroventricularly) or directly into the septum for 2 weeks beginning at the time of the transection. In vehicle-infused animals, only $28 \%$ of the ChAT-immunoreactive neurons remained on the side ipsilateral to the lesion compared to the contralateral intact side. When infused intracerebroventricularly, both BDNF and NGF reduced the extent of the phenotypic loss, in that $44 \%$ and $68 \%$, respectively, of the ChAT-immunopositive neurons remained on the lesioned side. Intraseptal infusion proved even more effective, in that following BDNF and NGF treatment $60 \%$ and $86 \%$, respectively, of the normal complement of ChAT-immunopositive neurons were apparent on the side ipsilateral to the lesion. Similar results were obtained when an antibody to the low-affinity NGF receptor was used to identify the cholinergic neurons. To determine if the apparent greater efficacy of NGF compared to BDNF might be related to differences in delivery, we examined the patterns of distribution of radiolabled BDNF and NGF injected into the lateral ventricle. ${ }^{225}$-BDNF showed only very little diffusion from the ventricles into the adjacent neural tissue and negligible retrograde labeling of the neurons within the basal forebrain. 125|-NGF, however, diffused readily into the brain, resulting in widespread retrograde labeling of basal forebrain neurons. A similarly limited distribution pattern was observed where BDNF was detected immunohistochemically in animals infused intracerebroventricularly $(12 \mu \mathrm{g} / \mathrm{d})$ for 2 weeks. In contrast, when delivered intraseptally, the same dose of

\footnotetext{
Received Nov. 6, 1992; revised Apr. 5, 1993; accepted Apr. 15, 1993.

We thank Drs. Leonard Schleifer and Jesse Cedarbaum for their interest and support, and our other colleagues at Regeneron for critical comments and helpful suggestions. We are grateful to Ingrid Van de Stadt and Dr. Nancy Ip for help with preliminary experiments.

Correspondence should be addressed to Drs. Ronald M. Lindsay and Ralph Alderson, Regeneron Pharmaceuticals Inc., 777 Old Saw Mill River Road, Tarrytown, NY 10591-6707.

Copyright (C) 1993 Society for Neuroscience 0270-6474/93/134146-11\$05.00/0
}

BDNF exhibited a widespread diffusion within the surrounding neuropil and retrograde labeling of neurons in the medial septum and the vertical limb of the diagonal band. Thus, when delivered effectively, BDNF has a substantial capacity to rescue axotomized cholinergic neurons.

[Key words: low-affinity NGF receptor, neurotrophins, septum, hippocampus]

The molecular cloning of brain-derived neurotrophic factor (BDNF; Leibrock et al., 1989) has revealed its close amino acid sequence homology with NGF and enabled, by homology cloning, the identification of a family of related trophic factors, termed the neurotrophins. Members of this family exhibit distinct yet overlapping patterns of neuronal specificity as well as different patterns of expression in the periphery and CNS (Bandtlow et al., 1987; Ernfors et al., 1990; Hohn et al., 1990; Maisonpierre et al., 1990a,b; Phillips et al., 1990; Rosenthal et al., 1990; Ceccatelli et al., 1991; Hallböök et al., 1991; Ip et al., 1993; for recent review, see Lindsay, 1993).

That BDNF supports the survival and phenotypic differentiation of cholinergic neurons was first suggested by cell culture experiments (Alderson et al., 1990; Knüsel et al., 1991). In lowdensity cultures, a two- to threefold increase in the survival of AChE-containing neurons as well as a two- to threefold increase in the level of ChAT enzyme activity was observed as a result of BDNF treatment. These responses to BDNF are similar to those previously described for NGF under equivalent culture conditions (Honegger and Lenoir, 1982; Hartikka and Hefti, 1988).

Consistent with the notion that BDNF may be a target-derived trophic factor for basal forebrain cholinergic neurons, Northern analysis has revealed high levels of BDNF mRNA in the hippocampus of both the developing and adult rat brain (Maisonpierre et al., 1990b). In situ hybridization studies, which further delineate the cellular distribution pattern of BDNF expression in the adult hippocampus, have shown relatively high levels of BDNF transcripts within pyramidal cells of the CA3 region and the granule and polymorphic cells of the dentate gyrus (Ernfors et al., 1990; Hofer et al., 1990; Phillips et al., 1990). In corroboration of these findings, BDNF immunoreactivity has been demonstrated in the pyramidal and hilar cells of the hippocampus (Wetmore et al., 1991). Also consistent with the hypothesis that BDNF may be a target-derived trophic factor, injection of ${ }^{125} \mathrm{I}-\mathrm{BDNF}$ into the hippocampus resulted in retrograde labeling of neurons within the medial septum and vertical limb of the diagonal band (DiStefano et al., 1992). These data are reminiscent of previous reports that described the ret- 
rograde transport of ${ }^{125} \mathrm{I}-\mathrm{NGF}$ from the hippocampus and neocortex to forebrain cholinergic nuclei (Schwab et al., 1979; Seiler and Schwab, 1984).

The fimbria is the major fiber bundle through which septal cholinergic neurons project to the hippocampus (Daitz and Powell, 1954; McKinney et al., 1983; Mesulam et al., 1983). The temporal sequence of the biochemical and cytological changes in the basal forebrain and hippocampus associated with the transection of this pathway have been well characterized (Daitz and Powell, 1954; Gage et al., 1986; Armstrong et al., 1987; Springer et al., 1987; Sofroniew and Isacson, 1988; Naumann et al., 1992). Within 1-2 weeks of transection there is a pronounced loss of AChE and ChAT immunoreactivity within both the medial septal nucleus and the hippocampus. Retrograde labeling studies carried out by several groups have clearly demonstrated that the decline in the phenotypic ncuronal markers is associated with the subsequent death of septal cholinergic neurons (O'Brien et al., 1990; Tuszynski et al., 1990). Numerous groups have characterized the ability of NGF to rescue basal forebrain cholinergic neurons from the lesion-induced loss of phenotypic markers and eventual cell death (Hefti, 1986; Williams et al., 1986; Batchelor et al., 1989; Hagg et al., 1989; Koliatsos et al., 1990; Tuszynski et al., 1990).

In this study, we have tested the ability of recombinant human $\mathrm{BDNF}$, as compared to mouse NGF, to maintain phenotypic characteristics of cholinergic neurons following transection of the fimbria. Buth intracerebroventricular and intraparenchymal routes of administration were used to compare the efficacy of BDNF and NGF infused continuously via osmotic pumps. We report herein that BDNF was more effective in maintaining the cholinergic phenotype when delivered intraparenchymally as compared to intracerebroventricular administration. A potential physiological mechanism accounting for this difference was investigated by distribution studies of BDNF, ${ }^{125} \mathrm{I}-\mathrm{BDNF}$, and ${ }^{125}$ I-NGF. These data demonstrate that BDNF has the capability to rescue basal forebrain cholinergic neurons from the effects of axotomy.

\section{Materials and Methods}

Adult Sprague-Dawley rats (200-250 gm; Zivic-Miller) were housed four per cage at $68-74^{\circ} \mathrm{F}$ on a $12: 12 \mathrm{hr}$ light : dark cycle. Food and water were available ad libitum. All animal related procedures were conducted in strict compliance with approved institutional protocols, and in accordance with provisions for animal care and use described in the Guide for the Care and Use of Laboratory Animals (NIH publication No. 86$23,1985)$.

\section{Fimbria transection studies}

Animals were anesthetized with a mixture of chloral hydrate $(170 \mathrm{mg} /$ $\mathrm{kg})$ and pentobarbital $(35 \mathrm{mg} / \mathrm{kg})$ and placed in a stereotaxic apparatus. A linear opening in the skull was made in the coronal plane, $1.6 \mathrm{~mm}$ posterior to bregma. The opening was approximately $5.0 \mathrm{~mm}$ in length, and extended from the left midline $(-0.5 \mathrm{~mm})$ to the right lateral edge of the dorsal surface of the skull $(+4.5 \mathrm{~mm})$. The fimbria was transected using an ophthalmic surgical blade, sharpened on both sides at the tip. The blade was inserted into the brain to a depth of $5.0 \mathrm{~mm}$. The initial penetration was made $0.5 \mathrm{~mm}$ lateral to midline to avoid disrupting the sagittal sinus. The blade was first moved medially to the midline and then advanced to the lateral margin of the craniotomy. This procedure was repeated three times, at insertion points 1,2 , and $3 \mathrm{~mm}$ lateral to the midline, to ensure complete transection of the fimbria.

Immediately after the completion of the transection procedure, a 0.5 $\mathrm{mm}$ burr hole was made at AP 0.0 (bregma), and $1.5 \mathrm{~mm}$ lateral to the midline to allow for the placement of cannulas into the right lateral ventricle. Osmotic pumps (model 2002, Alza Corp., Palo Alto, CA) were fillcd with recombinant human BDNF $(1 \mathrm{mg} / \mathrm{ml})$, mouse NGF (1 $\mathrm{mg} / \mathrm{ml})$, or vehicle solution ( $0.9 \%$ saline) and attached to the cannulas via $35 \mathrm{~mm}$ lengths of sterilized medical-grade vinyl tubing (Bolab Intravenous Medical Vinyl Tubing $v / 3$ ). The pumps were placed into a subdermal pocket in the intrascapular region and the osmotic pump connector cannulas (28 gauge, 4.5-5.0 mm long; Plastics One, Roanoke, VA) were bonded to the skull with a cyanoacrylate adhesive. The scalp incision was closed with wound clips and the animals were maintained under heat lamps until they revived from the anesthetic.

In a second series of animals, transections of the fimbria were made as described above, but the cannula was placed more medially, $0.6 \mathrm{~mm}$ to the right of midline, such that the tip of the cannula was located directly within the dorsolateral septum on the side of the lesion. The osmotic pumps were filled with BDNF (1 mg/ml), NGF $(200 \mu \mathrm{g} / \mathrm{ml})$, or $0.9 \%$ saline.

Histology. Two weeks postoperatively, vehicle-treated and growth factor-treated animals were anesthetized and perfused transcardially with heparinized saline, followed sequentially by $4 \%$ paraformaldehyde in acetate (pH 6.5) and borate buffers (pH 9.5) (Gerfen and Sawchenko, 1984). Osmotic pumps were removed from the animals at the time of death so that the amount of fluid remaining could be measured, providing verification that the pumps had functioned properly. Any fluid remaining in the pumps was relained for bioassay. As previously demonstrated, there was negligible loss in the biological activity of either NGF or BDNF, recovered from the pumps (Altar et al., 1992).

Following perfusion, brains were postfixed overnight and then placed in a 30\% sucrose-borate buffer solution ( $\mathrm{pH} 9.5$ ). After equilibrating in sucrose, $30 \mu \mathrm{m}$ frozen sections were cut in the coronal plane and stored at $-20^{\circ} \mathrm{C}$ in cryoprotectant (Watson et al., 1986). Sections collected at $180 \mu \mathrm{m}$ intervals (1-in-6 series) through the septum and hippocampus were stained with thionin and for AChE (Hedreen et al., 1985). Altemate 1 -in- 6 series of sections through the septum were immunostained for ChAT or low-affinity NGF receptor (LNGFR) using an avidin-biotinperoxidase procedure (Watson et al., 1986). To ensure equivalence of immunostaining among treatment groups, representative series of sections from BDNF-, NGF-, and vehicle-infused animals were processed concurrently. Tissue sections from a normal, unoperated animal were also processed in parallel with experimental tissues as an additional control for the intensity of immunostaining across runs. Primary antibodies used for immunostaining comprised a rabbit polyclonal antiserum raised against human placental ChAT (AB 143, Chemicon, lot $061191 \mathrm{LH}$ ) and a mouse monoclonal antibody raised against human LNGFR, mAb 192 (Chandler et al., 1984). Free-floating sections were incubated overnight at $4^{\circ} \mathrm{C}$ in a solution containing the primary antibody $(0.4 \mu \mathrm{g} / \mathrm{ml} \mathrm{mAb} 192$ and $1: 5000$ dilution of $\mathrm{AB} 143)$. For ChAT staining, the tissue was then placed in a fresh solution of primary antibody (1: 2500 ) and incubated for an additional $24 \mathrm{hr}$. After incubation in the primary antibodies, sections were incubated in a biotinylated secondary antibody solution for $1 \mathrm{hr}$ at room temperature. Affinity-purified horse anti-mouse IgG (1:200) and goat anti-rabbit IgG (1:1000) were used for LNGFR and ChAT staining, respectively (Vector Laboratories, Burlingame, CA). Sections were then incubated for $1 \mathrm{hr}$ in an avidin-biotinperoxidase complex (1:500; Vector Elite Kit), and the peroxidase visualized with diaminobenzidine (DAB). The DAB reaction product was intensified by inclusion of nickel(II) sulfate in the chromagen solution (Hancock, 1986). Stained sections were mounted on subbed glass slides and air dried. Some series immunostained for LNGFR were counterstained with pyronin $Y$ before being dehydrated in alcohols, cleared in xylenes, and coverslipped.

Analysis. To assess the effects of growth factors on cholinergic neuron loss, ChAT-and LNGFR-immunoreactive neurons were counted in the medial septum, ipsilateral and contralateral to the lesion. For the purposes of this analysis the anteroposterior extent of the medial septum was defined as beginning with the first appearance of the major Island of Calleja (AP +1.2) and ending immediately rostral to the crossing of the anterior commissure (AP -0.2) (Paxinos and Watson, 1986). In most animals, this comprised eight sections in each 1 -in- 6 series. The ventral boundary of the medial septum was defined as an imaginary line connecting the dorsal margins of the anterior limb of the commissure. Animals were included in this analysis if they met the following criteria; completeness of the fimbria lesion as assessed by the loss of AChE staining in the hippocampus, and proper location of the cannula tip as determined by examination of thionin-stained sections (i.e., location of the cannula in the lateral ventricle for the first experiment and in the dorsolateral septum for the second). These evaluations were made by an observer who was unaware of the treatment conditions. Animals 

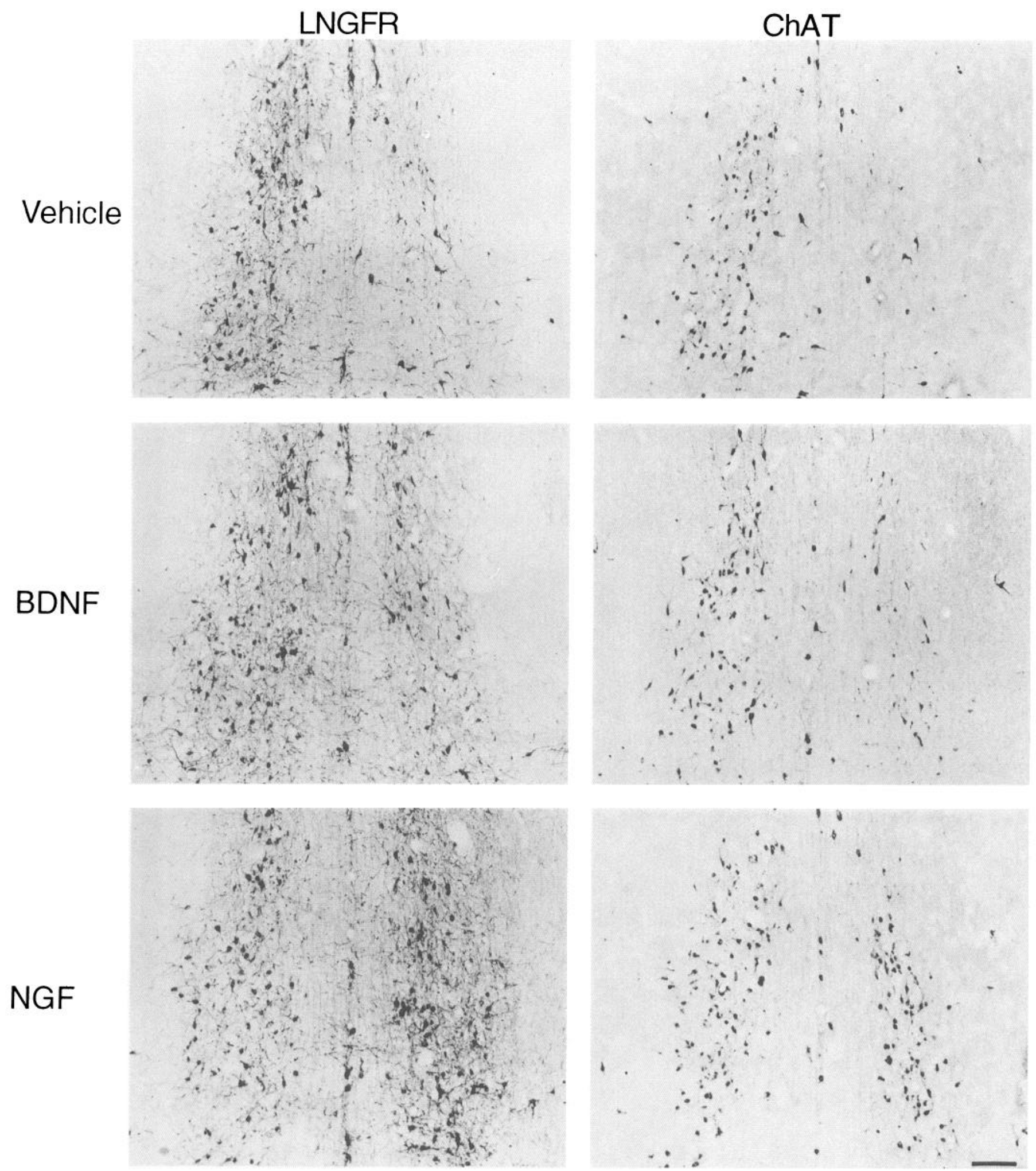

Figure 1. Photomicrographs illustrating the effect of fimbria-fornix transection on the number of septal neurons immunopositive for ChAT or LNGFR in animals treated intracerebroventricularly with vehicle, BDNF, or NGF. The intact side of the septum is to the left of each photomicrograph. Scale bar, $150 \mu \mathrm{m}$.

also were excluded if the pump had become disconnected from the cannula or failed to operate. Animals that met the above criteria also were excluded from the analysis in a few cases where ChAT-immunoreactive cells were only poorly stained on the intact side.

In each section, immunostained cells were counted on the operated and unoperated sides; cells lying on the midline were not counted Immunoreactive profiles were accepted as cells only if the perikaryon exhibited one or more distinct processes or contained a clearly defined nucleus (Tuszynski et al., 1990). Cell counts obtained for each side of the septum were added across all sections for each animal. Some of the 
data were then expressed as the ratio of immunostained neurons on the transected compared to the intact side. Analysis of variance and Dunnett's two-tailed $t$ test were used to evaluate differences among the treatment conditions.

\section{Distribution and transport of intracerebrally administered neurotrophins}

Detection of radiolabeled NGF and BDNF. The following experiments were performed to examine the diffusion and transport characteristics of NGF and BDNF following intracerebral injections. In the first series of experiments, recombinant human BDNF and mouse NGF were radioiodinated and their biological activity characterized as described previously (DiStefano et al., 1992). Animals were anesthetized as described above and $10 \mu \mathrm{l}$ of ${ }^{125}$ I-BDNF $(0.42 \mu \mathrm{g}, 36.7 \mu \mathrm{Ci})$ or ${ }^{125} \mathrm{I}-\mathrm{NGF}$ $(0.36 \mu \mathrm{g}, 38.7 \mu \mathrm{Ci})$ was injected stereotaxically into the right lateral ventricle by way of a 30 gauge needle attached to a $25 \mu \mathrm{l}$ Hamilton syringe. The animals were reanesthetized $90 \mathrm{~min}$ or $20-22 \mathrm{hr}$ postinjection and perfused transcardially with heparinized saline followed by buffered $4 \%$ paraformaldehyde. The brains were removed, sectioned, and processed for film and emulsion autoradiography (DiStefano et al., 1992).

Immunohistochemical detection of BDNF. Because acute injections of trace amounts of protein might not accurately reflect the distribution of larger amounts of trophic factor administered continuously, a second experiment was conducted in which the intracerebral distribution of BDNF delivered from osmotic minipumps was assessed immunohistochemically. Antibodies against recombinant human BDNF were generated by immunizing turkeys with purified BDNF in complete Freund's adjuvant for the first injection and in incomplete Freund's adjuvant for all subsequent injections. BDNF $(0.2 \mathrm{mg})$ was injected on days $1,7,21$, 35 , and 56, and antibody titers were checked by ELISA on blood samples taken on days 28 and 63 . The antiserum selected for use in the present immunochemical studies (lot 8C-679-1, AMGEN) had a titer of 1:20,000 as measured by ELISA, and recognized BDNF, but not recombinant human neurotrophin-4 (NT-4), recombinant human NT-3, or mouse salivary gland NGF on slot blots. The specificity of this antiserum was further tested by immunostaining sections taken from animals that had received an acute injection of BDNF into the striatum $(1 \mu \mathrm{g} / 0.5 \mu \mathrm{l})$ or continuous intrastriatal infusion of BDNF or NT -3 for $12 \mathrm{~d}(12 \mu \mathrm{g} / \mathrm{d})$. Tissue was prepared and sections were stained in a manner identical to that described for ChAT and LNGFR, using the anti-BDNF antiserum at a dilution of $1: 1000$ or $1: 5000$ and a biotinylated rabbit anti-turkey IgG secondary antiserum (Zymed Labs, Inc., San Francisco, CA) at a dilution of 1:1500. Intense staining was observed for BDNF but not for NT-3 at the intrastriatal injection or infusion sites. Preadsorption of the antiserum with $1 \mu \mathrm{g} / \mathrm{ml}$ BDNF overnight before incubation of tissue sections completely blocked staining. Staining was not observed when preimmune serum was used (lowest dilution tested, 1:200) in place of the primary antiserum, or when the antiserum was omitted from the primary incubation. On the other hand, staining intensity was not attenuated when the primary antiserum was preadsorbed with $1 \mu \mathrm{g} / \mathrm{ml}$ NT -3 or $100 \mu \mathrm{g} / \mathrm{ml}$ mouse NGF.

\section{Trophic factors}

Mouse NGF was prepared from adult male mouse salivary glands by the modified procedure of Suda et al. (1978). Recombinant human BDNF was produced in Escherichia coli and purified as previously described (DiStefano el al., 1992).
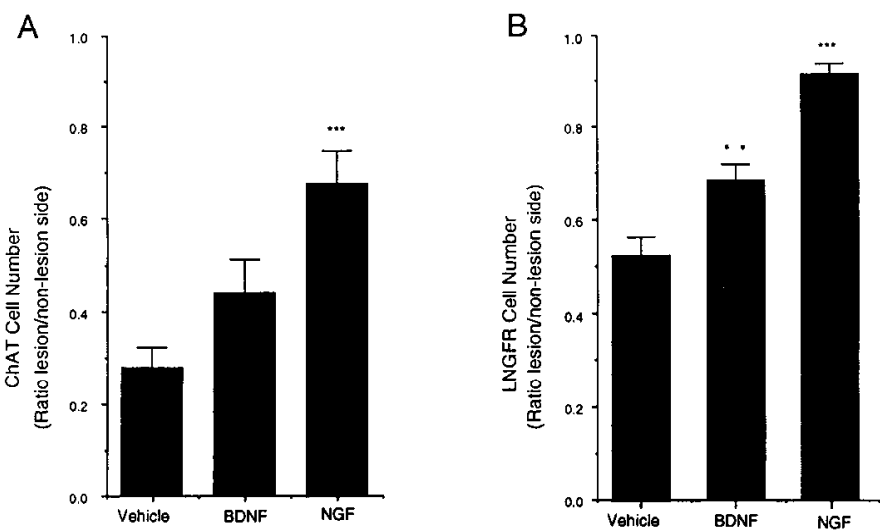

Figure 2. Histogram depicting the effect of intracerebroventricular delivery of vehicle, BDNF, and NGF on the number of ChAT-and LNGFRimmunopositive neurons. Cell counts were made in sections stained for either ChAT $(A)$ or LNGFR $(B)$ following transection of the fimbriafornix and a 2 week treatment with BDNF or NGF. The number of immunopositive neurons is expressed as a ratio of the lesioned versus the nonlesioned side. $N=11,10$, and 9 for vehicle, BDNF, and NGF, respectively, for the infused animals immunohistochemically stained for ChAT protein, and $N=10,10$, and 10 for animals immunohistochemically stained for LNGFR protein. ${ }^{* *}, p<0.002$, and ${ }^{* * *}, p<$ 0.0001 , comparing BDNF- and NGF- to the vehicle-infused animals, respectively.

\section{Results}

\section{Effect of intracerebroventricular infusion of BDNF and NGF} Two weeks after transection of the fimbria, a pronounced loss of ChAT was apparent on the operated side in vehicle-infused animals. In the BDNF-treated animals, there was a small reduction in the loss of ChAT-immunopositive neurons on the side ipsilateral to the lesion. However, NGF infused intracerebroventricularly had a pronounced effect on the rescue of ChATpositive neurons, as previously reported (Fig. 1; Hefti, 1986; Williams et al., 1986). In vehicle-infused animals the number of ChAT-positive cells ipsilateral to the fimbria lesion was only $28 \pm 4 \%$ of that on the intact side, whereas in animals receiving BDNF or NGF treatment $44 \pm 7 \%$ and $68 \pm 7 \%$ of the ChATimmunopositive neurons remained on the lesioned side, respectively (Fig. 2). Similar results were obtained when the cholinergic neurons were identified by labeling with an antibody to the LNGFR (Table 1). In vehicle-infused animals, the number of LNGFR-positive neurons on the side ipsilateral to the lesion was reduced to $52 \pm 4 \%$ of the contralateral intact side. This loss was attenuated to $68 \pm 3 \%$ and $91 \pm 2 \%$ in BDNF- and NGF-treated animals, respectively. The administration of NGF produced a statistically significant attenuation of cell loss as assessed by ChAT and LNGFR staining. However, BDNF treat-

Table 1. Effect of intracerebroventricular infusion of vehicle, BDNF, or NGF on the number of ChATand LNGFR-immunopositive neurons

\begin{tabular}{lllll} 
& \multicolumn{3}{c}{ Intact } & \multicolumn{3}{l}{ Transected } \\
\cline { 2 - 4 } \cline { 5 - 5 } Group & LNGFR & ChAT & LNGFR & ChAT \\
\hline Vehicle & $275.0 \pm 22.0$ & $217.2 \pm 34.9$ & $147.8 \pm 20.0$ & $59.4 \pm 11.6$ \\
BDNF & $279.6 \pm 18.3$ & $172.0 \pm 29.8$ & $191.8 \pm 16.9$ & $64.1 \pm 11.0$ \\
NGF & $248.1 \pm 10.0$ & $204.4 \pm 30.7$ & $226.3 \pm 10.0^{* *}$ & $124.6 \pm 10.0^{* * *}$
\end{tabular}

${ }^{* *}, p<0.01 ;{ }^{* * *}, p<0.001$; comparing NGF-infused lesioned groups and vehicle-infused lesioned groups. 
LNGFR
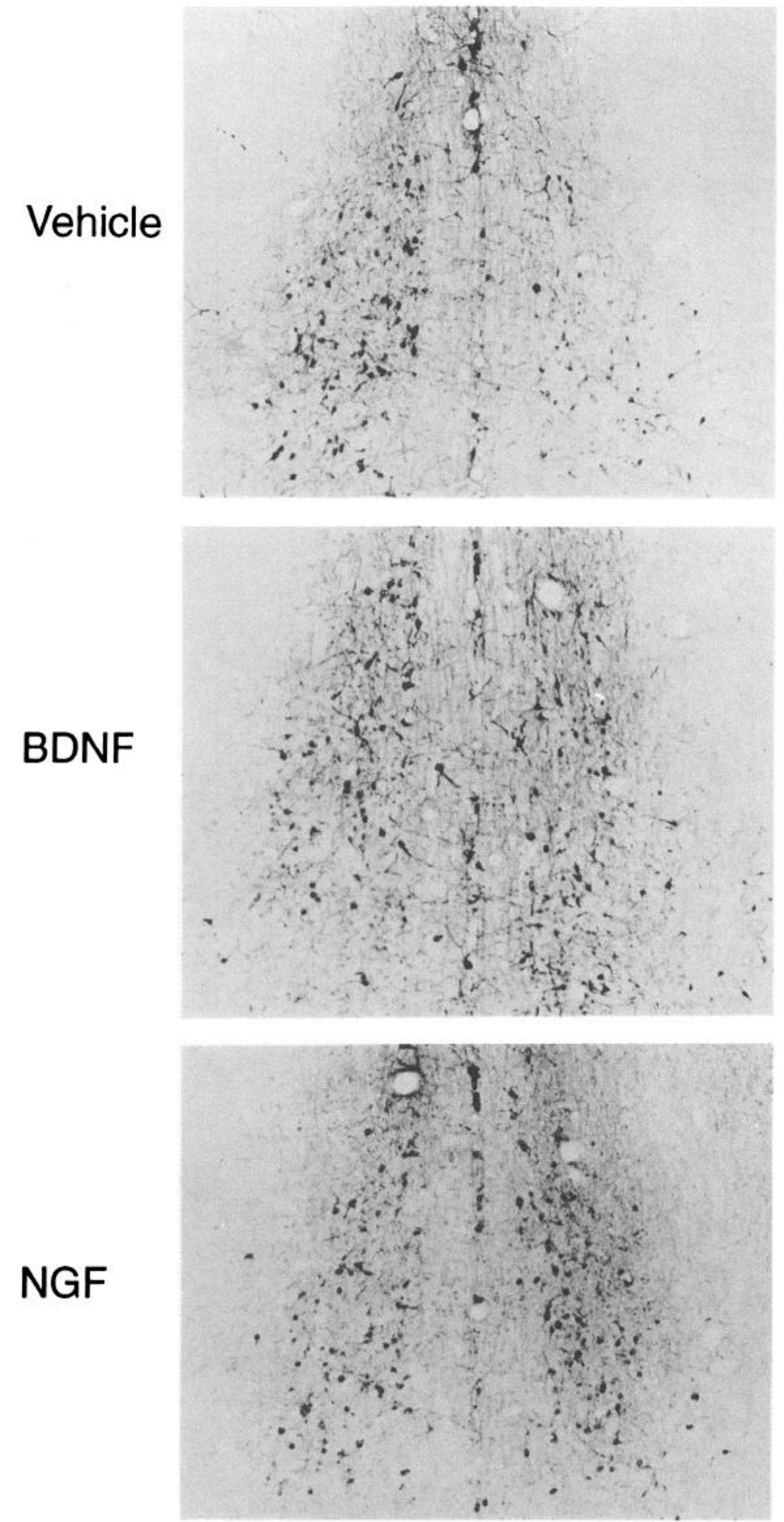

ChAT
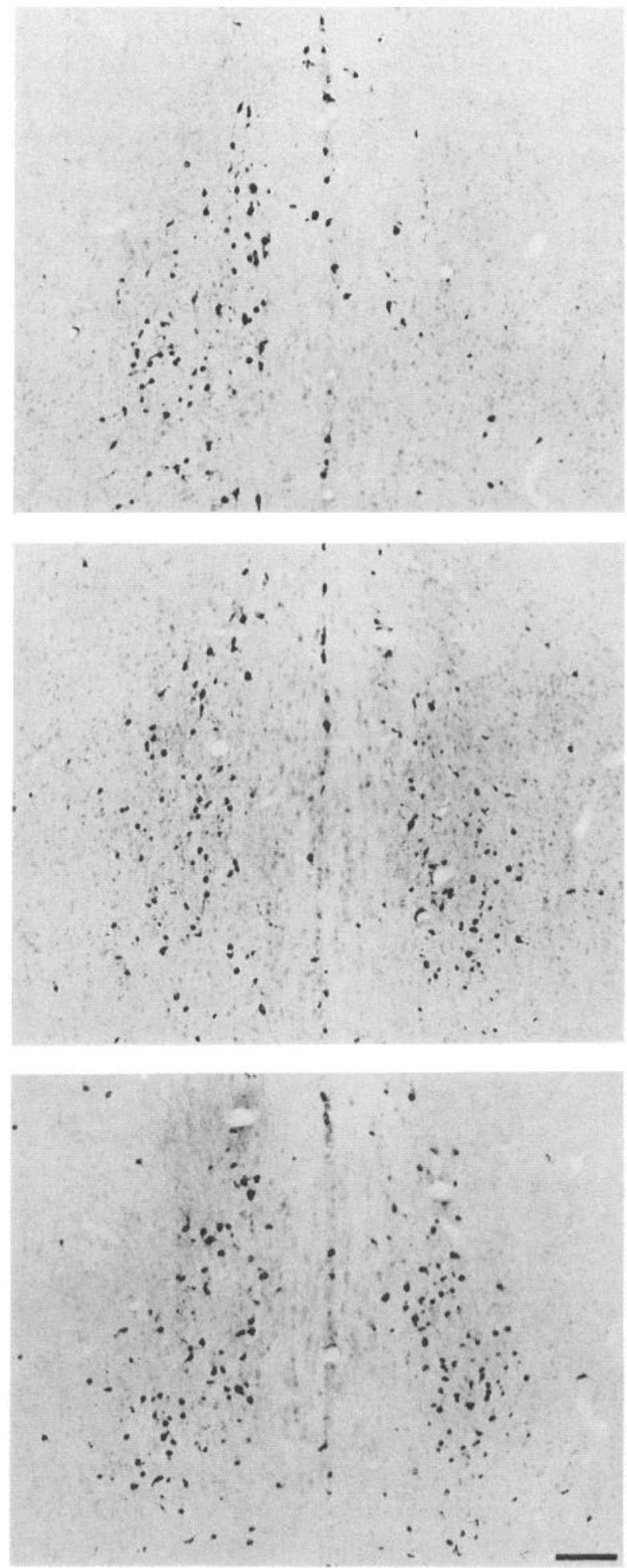

Figure 3. Photomicrographs illustrating the effect of fimbria-fornix transection on the number of septal neurons immunopositive for LNGFR or ChAT in animals treated intraseptally with vehicle, BDNF, or NGF. The intact side of the septum is to the left of each photomicrograph. Scale bar, $150 \mu \mathrm{m}$. 
ment produced a significant attenuation in the loss of LNGFRstained but not ChAT-stained neurons.

\section{Effect of intraseptal infusion of BDNF and NGF}

As the rescue effect with intracerebroventricularly administered BDNF was less than might have been expected on the basis of in vitro findings, we explored the effect of a more direct delivery of trophic factors by moving the cannulas to the caudal pole of the septum. The presence of the intraseptal cannulas by itself had no effect on the decline in the number of immunopositive neurons in the vehicle-infused animals. In vehicle-infused animals, $32 \pm 3 \%$ of the ChAT-immunopositive neurons remained on the side ipsilateral to the lesion as compared to the unlesioned contralateral side. BDNF and NGF treatments enhanced the preservation of cholinergic neurons ipsilateral to the transection to $60 \pm 5 \%$ and $86 \pm 5 \%$ of the intact side, respectively. Similar relative increases in the number of LNGFRimmunopositive cells, from $49 \pm 4 \%$ in vehicle infused animals to $77 \pm 3 \%$ and $84 \pm 3 \%$ in BDNF and NGF-infused animals, respectively, were noted. In terms of cell counts, $166 \pm 16$ LNGFR-immunopositive neurons remained on the operated side in the vehicle-treated animals compared to $248 \pm 19$ and $333 \pm 28$ in BDNF- or NGF-treated animals, respectively (Figs. $3,4)$. Moreover, the effect of direct intraseptal infusion of trophic factor was not confined to neurons nearest to the cannulas, but equally apparent at more rostral levels.

\section{Distribution and transport of BDNF and NGF}

It is clear from functional studies in both rodents and primates that NGF delivered into the lateral ventricle can diffuse for considerable distances into the adjacent brain parenchyma. Given that the effectiveness of BDNF delivered intracerebroventricularly was significantly less than that of NGF, we compared the distribution and transport characteristics of BDNF and NGF following intraccrcbroventricular administration of trace amounts of radiolabeled protein. In all experiments where radioiodinated BDNF was injected into the ventricles, diffusion into the adjacent brain tissue appeared to be very limited (Fig. $5 A$ ). In emulsion autoradiograms, a continuous and extremely dense band of silver grains was apparent over the apical (ventricular) surface of the ependyma. Labeling of the ependyma was more pronounced at the shorter survival time $(90 \mathrm{~min})$. A dense band of BDNF-associated label was also present immediately subjacent to the ependymal layer. From this point, the density of labeling decreased dramatically with distance, such that above-background labeling in the neuropil did not appear to extend more than $200-400 \mu \mathrm{m}$ from the ventricular surface. The distribution of grains within this area was relatively homogeneous; neuronal and glial cell bodies did not appear to incorporate ${ }^{125}$ I-BDNF selectively. Retrograde labeling of neurons within the medial septum and diagonal band was not apparent in animals killed 20-22 hr after administration of $125 \mathrm{I}$ BDNF (Fig. 5A). In marked contrast to the pattern described above for ${ }^{125} \mathrm{I}-\mathrm{BDNF}$, ${ }^{125} \mathrm{I}$-NGF injected intracerebroventricularly diffused a considerable distance into the adjacent brain substance. At 90 min postinjection, NGF-associated label was densest at the level of the injection site and extended for 2-3 $\mathrm{mm}$ into the adjacent neural tissues. At $22 \mathrm{hr}$ postinjection, diffusely distributed NGF-associated label remained apparent in the neuropil adjacent to the injection site (Fig. $5 B$ ). In addition, neurons of the basal forebrain cholinergic system were
A

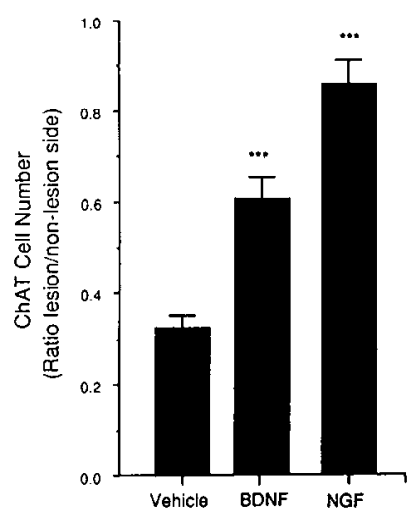

B

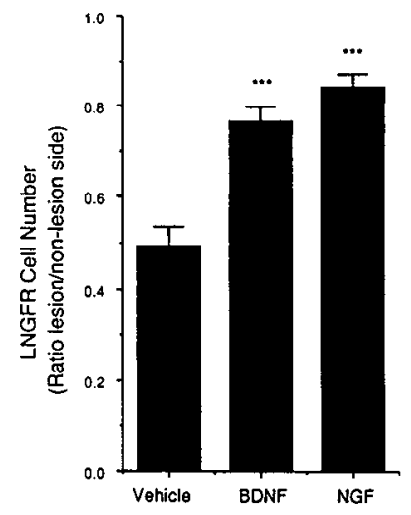

Figure 4. Histogram depicting the effect of intraseptal delivery of vehicle, BDNF, and NGF on the number of ChAT and LNGFR-immunopositive neurons following fimbria-fornix transection. $A, N=8,11$, and 7 for vehicle-, BDNF-, and NGF-infused animals immunohistochemically stained for ChAT protein. ${ }^{* *}, p<0.0001$ comparing BDNF or NGF infusion, respectively, to the vehicle-infused control animals. $B, N=14,15$, and 7 for vehicle-, BDNF-, and NGF-infused animals immunohistochemically stained for LNGFR protein.

densely labeled bilaterally, particularly within the medial septum and diagonal band nuclei.

A remarkably similar pattern of BDNF distribution was apparent in experiments that employed chronic intracerebroventricular administration of unlabeled protein ( $12 \mu \mathrm{g} / \mathrm{d}$ for 2 weeks). BDNF-like immunoreactivity was restricted to a relatively narrow band of periventricular tissues. Diffuse immunostaining at above-background levels did not extend more than 300-500 $\mu \mathrm{m}$ into the brain, even in those areas adjacent to the tip of the cannula (Fig. 5C). Relatively few neurons within the medial septum and vertical limb of the diagonal band appeared to have incorporated and retrogradely transported the intracerebroventricularly infused BDNF, as evidenced by the presence of punctate, BDNF-immunoreactive profiles within the perikarya. Cells that transported BDNF were invariably lightly labeled and present only on the side of the infusion. A strikingly different pattern of BDNF distribution was apparent in cases where BDNF was delivered directly into the septum (Fig. SD). BDNF immunoreactivity was densely distributed within the tissue around the cannula tip, describing a roughly spherical zone of diffusion with a radius of approximately $1.5 \mathrm{~mm}$. Furthermore, many retrogradely labeled neurons were present within the medial septum and vertical limb of the diagonal band in animals that received direct intraseptal infusions of BDNF (Fig. 6A). The majority of BDNF-labeled neurons were found ipsilateral to the side of the infusion; labeled neurons were distinctly fewer in number on the contralateral side and generally were more lightly labeled. BDNF-like immunoreactivity was not apparent either at the infusion site or within neurons of the medial septum and diagonal band in animals receiving intracerebroventricular or intraseptal infusions of NGF or vehicle (Fig. $6 B$ ).

\section{Discussion}

In vitro studies investigating the effect of neurotrophic factors on embryonic cholinergic neurons have demonstrated the responsiveness of this cell population to BDNF on the basis of 

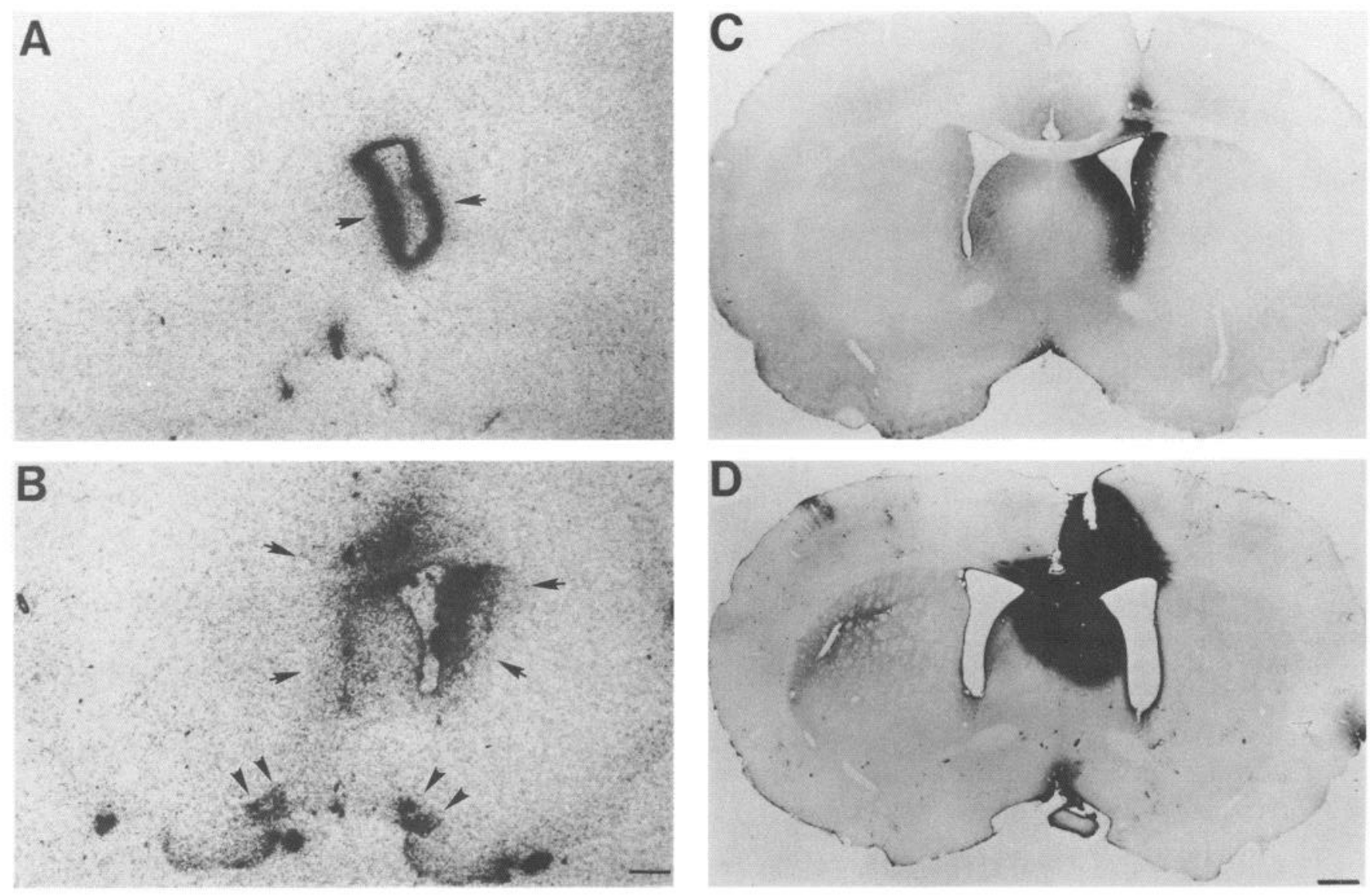

Figure 5. Photomicrographs illustrating the distribution patterns of BDNF and NGF following intracerebral injection. Autoradiograms of tissue taken $22 \mathrm{hr}$ after acute intracerebroventricular infusions of ${ }^{125} \mathrm{I}-\mathrm{BDNF}$ and ${ }^{125} \mathrm{I}-\mathrm{NGF}$ are illustrated in $A$ and $B$, respectively. Arrows mark the limit of diffusion of labeled trophic factor from the injection site. Arrowheads indicate retrogradely labeled neurons in the horizontal limb of the diagonal band. $C$ and $D$ are photomicrographs of BDNF-like immunoreactivity following chronic (12 $\mu \mathrm{g} / \mathrm{d}$ for 2 weeks) intracerebroventricular (C) or intraseptal $(D)$ infusions of BDNF. Scale bars, $650 \mu \mathrm{m}$.

both enhanced cell survival and phenotypic differentiation (Alderson et al., 1990). The possibility that basal forebrain cholinergic neurons may be responsive to BDNF in vivo is supported by recent studies that demonstrated that ${ }^{125} \mathrm{I}-\mathrm{BDNF}$, when injected into the hippocampus, is retrogradely transported by neurons of the medial septum and vertical limb of the diagonal band (DiStefano et al., 1992). These findings for BDNF are reminiscent of those obtained for NGF (Schwab et al., 1979), which were predictive of both physiological and pharmacological effects of NGF on the septohippocampal pathway in adult rats and primates (Gage et al., 1986; Honegger et al., 1986; Hefti 1986; Williams et al., 1986; Fischer et al., 1987; Hartikka and Hefti, 1988; Koliatsos et al., 1990; Tuszynski et al., 1990).

In the present study, results obtained with NGF using an intracerebroventricular route of administration were in agreement with those previously reported. However, BDNF, administered by the same route and at an identical concentration, proved to be less effective. The latter finding is contrary to those obtained from in vitro studies that demonstrated that BDNF and NGF were equipotent in maintaining the survival and phenotype of cholinergic neurons. However, the fact that the efficacy of BDNF was greatly increased when administered into the septum tends to rule out the possibility that mature neurons are much less responsive to BDNF than during their development. Rather, these results suggest that NGF might be more readily accessible to those neurons than BDNF when the factors were infused intracerebroventricularly. This hypothesis was confirmed by comparing the distribution pattern of intracerebroventricularly infused ${ }^{125} \mathrm{I}-\mathrm{NGF}$ with that of ${ }^{125} \mathrm{I}$-BDNF. Twenty hours after intracerebroventricular injection, ${ }^{125} \mathrm{I}-\mathrm{NGF}$ could be localized to neurons in the medial septum, vertical and horizontal limbs of the diagonal band, and the nucleus basalis, a distribution resembling the pattern of retrograde transport observed following direct injection of ${ }^{125} \mathrm{I}-\mathrm{NGF}$ into the hippocampus and cortex (Schwab et al., 1979; Seiler and Schwab, 1984). An identical pattern of NGF transport in the forebrain following intracerebroventricular injection has recently been reported by Ferguson et al. (1991). In contrast, studies that employed tracer amounts of radiolabeled BDNF demonstrated that there was substantial binding to the ependymal lining with limited penetration into the subjacent neural parenchyma. Furthermore, BDNF was not retrogradely transported to an appreciable degree by any neuronal population within the brain following intracerebroventricular injection, including the cholinergic nuclei of the basal forebrain. This stands in marked contrast to the extensive retrograde transport of BDNF within non-cholinergic as well as cholinergic neurons following direct infusion into the hippocampus (DiStefano et al., 1992).

To confirm the distribution pattern observed with the radiolabeled proteins and to assess whether differences in the total 

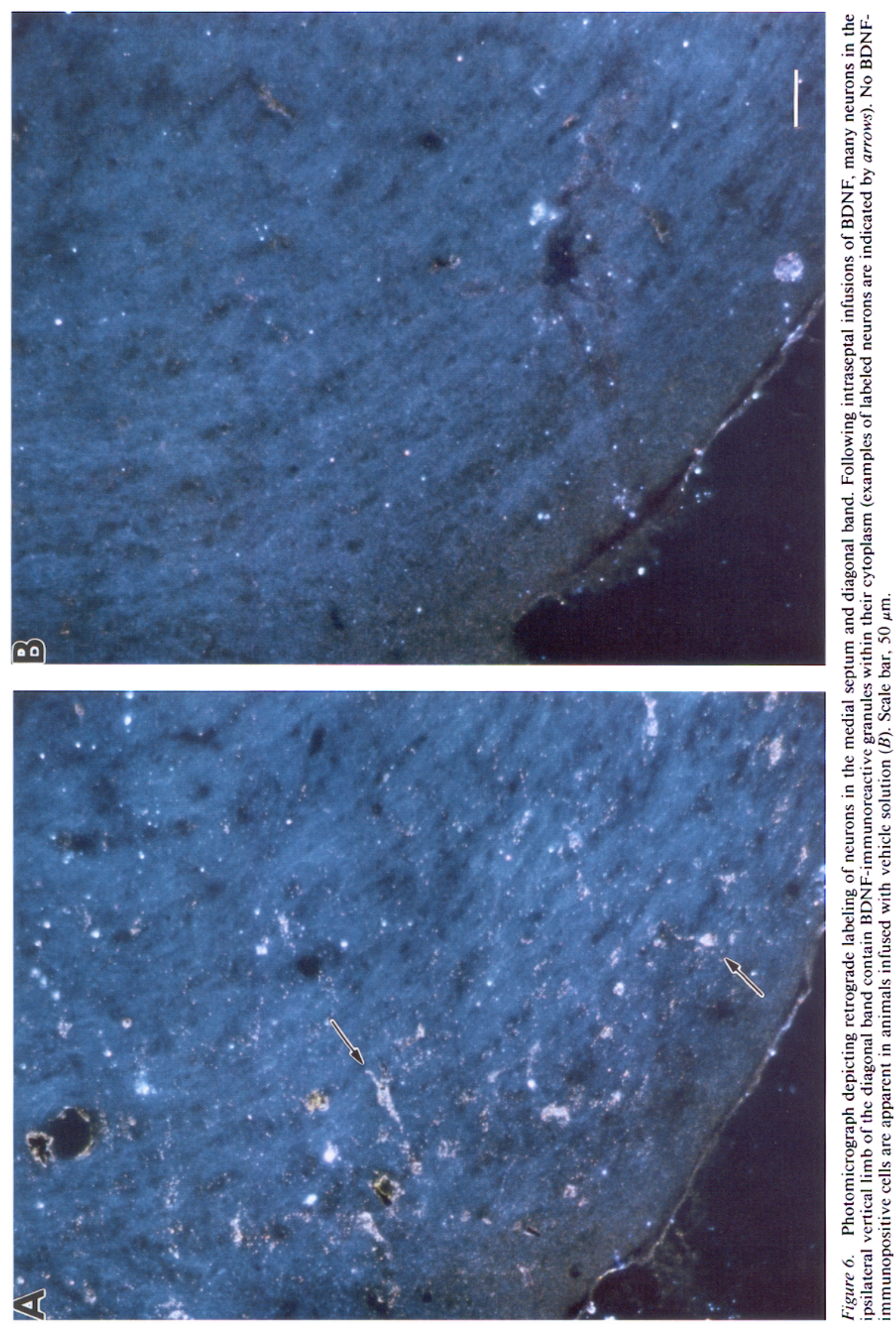

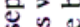

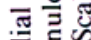
可㻤 更

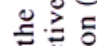
들 空客 产产号 需皮 at: 政 ज. 诺

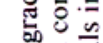
ํํㄹำ 这是

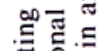

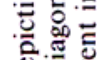
要要 등 錮 त्य ㅇํㅇำ 政 등 这 $\circ$ 응 는 氙 
concentration of injected trophic factor and the duration of administration might alter this pattern of distribution, studies were performed in which pharmacological doses of BDNF were administered via osmotic pumps and the protein localized immunohistochemically. In spite of the notable differences in the experimental paradigms, a similarly limited distribution of unlabeled BDNF was apparent following intracerebroventricular infusions. In contrast, when BDNF was administered intraseptally, BDNF immunoreactivity was densely distributed throughout the neuropil surrounding the cannula tip. Furthermore, retrograde labeling of neurons in the medial septum and diagonal band was much more extensive in cases where BDNF was administered intraseptally rather than intracerebroventricularly.

Although NGF and BDNF are structurally similar, they have distinct high-affinity receptors, termed TrkA and TrkB, respcctively (Klein et al., 1989, 1991a,b; Cordon-Cardo et al., 1991; Soppet et al., 1991; Squinto et al., 1991). The distribution of trkA transcripts is highly discrete and in the adult forebrain is localized to neurons in the striatum and basal forebrain nuclei (Vazquez and Ebendal, 1991; Wiegand et al., 1991). This is consistent with the distribution of forebrain cholinergic neurons that are responsive to NGF. In addition to expression as a fulllength receptor with a catalytic tyrosine kinase domain, TrkB is also expressed in truncated form(s) that lacks the kinase domain (Klein et al., 1989). Whereas full-length $t r k B$ transcripts have been shown by in situ analysis to be present in neurons widely distributed throughout the forebrain, the adult mouse hippocampal pyramidal cell layer, and dentate gyrus, the pattern of expression of the truncated $t r k \mathbf{B}$ receptor is very different. High levels of expression of the truncated receptor were most evident in the choroid epithelium and ependyma (Klcin ct al., 1990; Vazquez and Ebendal, 1991). Thus our finding that ${ }^{125} \mathrm{I}-$ BDNF binds to the ventricular ependyma in the rat is correlated with the presence of truncated TrkB. Numerous reports have documented the loss of basal forebrain cholinergic neurons in the latter stages of Alzheimer's disease (AD). These results along with those from rodent and primate studies (Hefti, 1986; Honegger et al., 1986; Williams et al., 1986; Gage et al., 1986; Hartikka and Hefti, 1988; Hagg et al., 1989; Koliatsos et al., 1991; Tuszynski et al., 1990), show that NGF can ameliorate the loss of this particular neuronal population, suggest a potential clinical utility for NGF in AD. However, other neuronal populations in addition to the basal forebrain cholinergic neurons, and these do not appear to be responsive to NGF, are affected in dementia and AD pathologies (Coyle et al., 1983). Receptor binding and retrograde transport studies demonstrate that many more neuronal types bind and transport BDNF than NGF (DiStefano et al., 1992; Wiegand et al., 1991, 1992; Altar et al., 1993). Furthermore, experiments that have employed Northern analysis and in situ hybridization have demonstrated a far more widespread distribution pattern for BDNF and $t r k \mathrm{~B}$ as compared to the more narrowly delineated expression pattern of NGF and trkA (Ernfors et al., 1990; Hofer et al., 1990; Maisonpierre et al., 1990; Phillips et al., 1990). Thus, the above findings as well as tissue culture and animal efficacy studies (Hyman et al., 1991; Knüsel et al., 1991; Larkfors et al., 1991; Altar et al., 1992; Ip et al., 1993) demonstrate that more neuronal types, which are susceptible to degeneration in $A D$ and other neurodegenerative diseases, are responsive to BDNF and not NGF. It has been suggested that decreases in the level(s) of neurotrophic factors in selected brain regions may be a causative factor in a variety of neurodegenerative diseases, including AD
(Appel, 1981). In the case of AD, this hypothesis has not been supported by experimental evidence for NGF or the LNGFR mRNA (Goedert et al., 1986, 1989; Hefti and Mash, 1989; Higgins and Mufson, 1989; Kordower et al., 1989; Phillips et al., 1991). In contrast, a loss of BDNF may be associated with the etiology of the disease as suggested by recent in situ hybridization studies, that show a decrease in the level of BDNF but not NGF mRNA in the hippocampus of brains from AD patients as compared to age-matched controls (Phillips et al., 1991). Taken together, these data indicate that BDNF may be relevant in the particular pathology and potential treatment of AD.

\section{References}

Alderson RF, Alterman AL, Barde Y-A, Lindsay RM (1990) Brainderived neurotrophic factor increases survival and differentiated functions of rat septal cholinergic neurons in culture. Neuron 5:297-306.

Altar CA, Boylan CB, Jackson C, Hershenson S, Miller J, Wiegand SJ, Lindsay RM, Hyman C (1992) Brain-derived neurotrophic factor augments rotational behavior and nigrostriatal dopamine turnover in vivo. Proc Natl Acad Sci USA 89:11347-11351.

Altar CA, Criden M, Lindsay RM, DiStefano PS (1993) Characterization and topography of high affinity $\left.{ }^{[25} \mathrm{I}\right]-$ neurotrophin 3 binding to mammalian brain. J Neurosci 13:733-743.

Appel SH (1981) A unifying hypothesis for the cause of amyotrophic lateral sclerosis, parkinsonism, and Alzheimer's disease. Ann Neurol 10:499-505.

Armstrong DM, Terry RD, DeTeresa RM, Bruce G, Hersh LB, Gage FH (1987) Response of septal cholinergic neurons to axotomy. J Comp Neurol 264:421-436.

Bandtlow CE, Heumann R, Schwab ME, Thoenen H (1987) Cellular localization of nerve growth factor synthesis by in situ hybridization. EMBO J 6:891-899.

Batchelor PE, Armstrong DM, Blaker SN, Gage FH (1989) Nerve growth factor receptor and choline acetyltransferasc colocalization in neurons within the rat forebrain: response to fimbria-fornix transection. J Comp Neurol 284:187-204.

Ceccatelli S, Ernfors P, Villar MJ, Persson H, Hökfelt T (1991) Expanded distribution of mRNA for nerve growth factor, brain-derived neurotrophic factor, and neurotrophin-3 in the rat brain after colchicine treatment. Proc Natl Acad Sci USA 88:10352-10356.

Chandler CE, Parsons LM, Hosang M, Shooter EM (1984) A monoclonal antibody modulates the interaction of nerve growth factor with PC1 2 cells. J Biol Chem 259:6882-6889.

Cordon-Cardo C, Tapley P, Jing S, Nanduri V, O'Rourke E, Lamballe F, Kovary K, Klein R, Jones KR, Reichardt LF, Barbacid M (1991) The trk tyrosine protein kinase mediates the mitogenic properties of nerve growth factor and neurotrophin-3. Cell 66:173-183.

Coyle JT, Price DL, Delong MR (1983) Alzhcimcr's discasc: a disease of cortical cholinergic innervation. Science 219:1184-1189.

Daitz HM, Powell TPS (1954) Studies on the connexions of the fornix system. J Neurol Neurosurg Psychiatry 17:75-82.

DiStefano PS, Friedman B, Radziejewski C, Alexander C, Boland P, Schick CM, Lindsay RM, Wiegand SJ (1992) The neurotrophins BDNF, N'I3 and NGF display distinct patterns of retrograde axon transport in peripheral and central neurons. Neuron 8:983-993.

Ernfors P, Wetmore C, Olson L, Persson H (1990) Identification of cells in rat brain and peripheral tissues expressing mRNA for members of the nerve growth factor family. Neuron 5:511-526.

Ferguson IA, Schweitzer JB, Bartlett PF, Johnson EM Jr (1991) Receptor-mediated retrograde transport in CNS neurons after intraventricular administration of NGF and growth factors. J Comp Neurol 313:680-692.

Fischer W, Wictorin K, Björklund A, Williams LR, Varon S, Gage FH (1987) Amelioration of cholinergic neuron atrophy and spatial memory impairments in aged rats by nerve growth factor. Nature 329:6568.

Gage FH, Wictorin K, Fischer W, Williams LR, Varon S, Björklund A (1986) Retrograde cell changes in medial septum and diagonal band following fimbria-fornix transection: quantitative temporal analysis. Neuroscience 19:241-255.

Gerfen CR, Sawchencko PE (1984) An anterograde neuroanatomical tracing method that shows the detailed morphology of neurons, their 
axons and terminals immunohistochemical localization of axonally transported plant lectin, Phaseolus vulgaris leucoagglutinin (PHA-L). Brain Res 290:219-238.

Goedert M, Fine A, Hunt SP, Ullrich A (1986) Nerve growth factor mRNA in peripheral and central rat tissues and in the human central nervous system: lesion effects in the rat brain and levels in Alzheimer's disease. Mol Brain Res 1:85-92.

Goedert M, Fine A, Dawburn D, Wilcock GK, Chao MV (1989) Nerve growth factor receptor $m R N A$ distribution in human brain: normal levels in basal forebrain in Alzheimer's disease. Mol Brain Res 5:1-7.

Hagg T, Fass-Holmes B, Vahlsing HL, Manthorpe M, Conner JM, Varon $S$ (1989) Nerve growth factor (NGF) reverses axotomy-induced decreases in choline acetyltransferase, NGF receptor and size of medial septum cholinergic neurons. Brain Res 505:29-38.

Hallböök F, Ibáñez CF, Persson H (1991) Evolutionary studics of nerve growth factor family reveal a novel member abundantly expressed in Xenopus ovary. Neuron 6:845-858.

Hancock MB (1986) Two-color immunoperoxidase staining: visualization of anatomic relationships between immunoreactive neuroelements. Am J Anat 175:343-352.

Hartikka J, Hefti F (1988) Development of septal cholinergic neurons in culture: plating density and glial cells modulate effects of NGF on survival fiber growth, and expression of transmitter specific enzymes. J Neurosci 8:2967-2985.

Hedreen JC, Bacon SV, Price DL (1985) A modified histochemical technique to visualize acetylcholinesterase containing axons. $J$ Histochem Cytochem 33:134-140.

Hefti F (1986) Nerve growth factor promotes survival of septal cholinergic neurons after fimbrial transections. J Ncurosci 6:21 55-2161.

Hefti F, Mash DC (1989) Localization of nerve growth factor receptors in normal human brain and in Alzheimer's disease. Neurobiol Aging 10:75-87.

Higgins GA, Mufson EJ (1989) NGF receptor gene expression is decreased in the nucleus basalis in Alzheimer's disease. Exp Neurol 106 222-236.

Hofer M, Pagliusi SR, Hohn A, Leibrock J, Barde Y-A (1990) Regional distribution of brain-derived neurotrophic factor $m R N A$ in the adult mouse brain. EMBO J 9:2459-2464.

Hohn A, Leibrock J, Bailey K, Barde Y-A (1990) Identification and characterization of a novel member of the nerve growth factor/brainderived neurotrophic factor family. Nature 344:339-341.

Honegger P, Lenoir D (1982) Nerve growth factor (NGF) stimulation of cholinergic telencephalic neurons in aggregating cell cultures. Dcv Brain Res 3:229-238.

Honegger P, DuPasquier P, Tenot M (1986) Cholinergic neurons of fetal rat telencephalon in aggregated cell culture respond to NGF as well as to protein kinase C-activating tumor promoters. Dev Brain Res 29:217-223.

Hyman C, Hofer M, Barde Y-A, Juhasz M, Yancopoulos GD, Squinto SP, Lindsay RM (1991) BDNF is a neurotrophic factor for dopaminergic neurons of the substantia nigra. Nature 350:230-232.

Ip NY, Li Y, Yancopoulos GD, Lindsay RM (1993) Cultured hippocampal neurons show responses to BDNF, NT3, and NT4 but not NGF. J Neurosci, in press.

Klein R, Parada RF, Coulier F, Barbacid M (1989) trkB, a novel tyrosine protein kinase receptor expressed during mouse neural development. EMBO J 8:3701-3709.

Klein R, Conway D, Parada LF, Barbacid M (1990) The trkB tyrosine kinase gene codes for a second neurogenic receptor that lacks the catalytic kinase domain. Cell 61:647-656.

Klein R, Jing S, Nanduri V, O'Rourke E, Barbacid M (1991a) The trk proto-oncogene encodes a receptor for nerve growth factor. Cell 65:189-197.

Klein R, Nanduri V, Jing S, Lamballe F, Tapley $P$, Bryant S, CordonCardo C, Jones KR, Reichardt L, Barbacid M (1991b) The trk B tyrosine kinase is a receptor for brain-derived neurotrophic factor and neurotrophin-3. Cell 66:395-403.

Knüsel B, Winslow JW, Rosenthal A, Burton LE, Seid DP, Nikolics K, Hefti F (1991) Promotion of central cholinergic and dopaminergic neuron differentiation by brain derived neurotrophic factor but not neurotrophin 3. Proc Natl $\Lambda$ cad Sci USA 88:961-965.

Koliatsos VE, Nauta HJW, Clatterbuck RE, Holtzman DM, Mobley WC, Price DL (1990) Mouse nerve growth factor prevents degeneration of axotomized basal forebrain cholinergic neurons in the monkey. J Neurosci 10:3801-3813.
Kordower JH, Gash DM, Bothwell M, Hersh II, Mufson EJ (1989) Nerve growth factor receptor and choline acetyltransferase remain co-localized in the nucleus basalis (Ch4) of Alzheimer's patients. Neurobiol Aging 10:287-294.

Lärkfors L, Alderson RF, Panayotatos N, Radziejewski C, Lindsay RM (1991) Effects of neurotrophins and CNTF on cerebellar Purkinje cell development in vitro. IBRO World Congr Neurosci 3:46.

Leibrock J, Lottspeich F, Hohn A, Hengerer B, Masiakowski P, Thoenen $\mathrm{H}$, Barde Y-A (1989) Molecular cloning and expression of brainderived neurotrophic factor. Nature 341:149-152.

Lindsay RM (1993) Brain-derived neurotrophic factor an NGF-related neurotrophin. In: Neurotrophic factors (Fallon JA, Loughlin SE, eds), pp 257-284. New York: Academic

Maisonpierre PC, Belluscio L, Squinto S, Ip NY, Furth ME, Lindsay RM, Yancopoulos GD (1990a) Neurotrophin-3: a neurotrophic factor related to NGF and BDNF. Science 247:1446-1451.

Maisonpierre PC, Belluscio L, Friedman B, Alderson RF, Wiegand SJ, Furth ME, Lindsay RM, Yancopoulos GD (1990b) NT-3, BDNF and NGF in the developing rat nervous system: parallel as well as reciprocal patterns of expression. Neuron 5:501-509.

McKinney M, Coyle JT, Hedreen JC (1983) Topographic analysis of the innervation of the rat neocortex and hippocampus by the basal forebrain cholinergic system. J Comp Neurol 217:103-121.

Mesulam MM, Mufson EJ, Wainer BH, Levey AI (1983) Central cholinergic pathways in the rat: an overview based on an alternative nomenclature (CH1-CH6). Neuroscience 10:1185-1201.

Naumann T, Peterson GM, Frotscher M (1992) Fine structure of rat septohippocampal neurons: II. A time course analysis following axotomy. J Comp Neurol 325:219-242.

O'Brien TS, Svendsen CN, Isacson O, Sofroniew MB (1990) Loss of true blue labelling from the medial septum following transection of the fimbria-fornix: evidence for the death of cholinergic and noncholinergic neurons. Brain Res 508:249-256.

Paxinos G, Watson C (1986) The rat brain in sterotaxic coordinates, 2d ed. New York: Academic.

Phillips HS, Hains JM, Laramee GR, Rosenthal A, Winslow JW (1990) Widespread expression of BDNF but not NT3 by target areas of basal forebrain cholinergic neurons. Science 250:290-294.

Phillips HS, Hains JM, Armanini M, Laramee GR, Johnson SA, Winslow JW (1991) BDNF mRNA is decreased in the hippocampus of individuals with Alzheimer's disease. Neuron 7:695-702.

Rosenthal A, Goeddel DV, Nguyen T, Lewis M, Shih A, Laramee GR, Nikolics K, Winslow JW (1990) Primary structure and biological activity of a novel human neurotrophic factor. Neuron 4:767-773.

Schwab ME, Otten U, Agid Y, Thoenen H (1979) Nerve growth factor (NGF) in the rat CNS: absence of specific retrograde axonal transport and tyrosine hydroxylase induction in locus coeruleus and substantia nigra. Brain Res 168:473-483.

Seiler M, Schwab ME (1984) Specific retrograde transport of nerve growth factor (NGF) from neocortex to nucleus basalis in the rat. Brain Res 300:33-39.

Sofroniew MV, Isacson O (1988) Distribution of degeneration of cholinergic neurons in the septum following axotomy in different portions of the fimbria-fornix: a correlation between degree of cell loss and proximity of neuronal somata to the lesion. J Chem Neuroanat 1:327337.

Soppct D, Escandon E, Maragos J, Middlemas DS, Reid SW, Blair J, Burton LE, Stanton BR, Kaplan DR, Hunter T, Nikolics K, Parada LF (1991) The neurotrophic factors brain-derived neurotrophic factor and neurotrophin 3 are ligands for trk $B$ tyrosine kinase receptor. Cell 65:895-903

Springer JE, Koh S, Tayrien MW, Loy R (1987) Basal forebrain magnocellular neuron: stain for nerve growth factor receptor: correlation with cholinergic cell bodies and effects of axotomy. J Neurosci Res 17:111-118.

Squinto SP, Stitt TN, Aldrich TH, Davis S, Bianco SM, Radziejewski C, Glass DJ, Masiakowski P, Furth ME, Valenzuela DM, DiStefano PS, Yancopoulos GD (1991) Trk B encodes a functional receptor for brain-derived neurotrophic factor and neurotrophin-3 but not nerve growth factor. Cell 65:885-893.

Suda K, Barde Y-A, Thoenen H (1978) Nerve growth factor in mouse and rat serum: correlation between bioassay and radioimmunoassay determinations. Proc Natl Acad Sci USA 75:4042-4046.

Tuszynski MH, Armstrong DM, Gage FH (1990) Basal forebrain cell loss following fimbria-fornix transection. Brain Res 508:241-248. 
Vazquez ME, Ebendal T (1991) Messenger RNA for trk and the lowaffinity NGF receptor in rat basal forebrain. Neuroreport 2:593-596.

Watson RE Jr, Wiegand SJ, Clough RL, Hoffmann GE (1986) Use of cyroprotectant to maintain long-term peptide immunoreactivity and tissue morphology in free-floating sections. Peptides 7:155-159.

Wetmore C, Cao Y, Pettersson RF, Olson L (1991) Brain-derived neurotrophic factor: sub-cellular compartmentalization and interneuronal transfer as visualized with anti-peptide antibodies. Proc Natl Acad Sci USA 88:9843-9847.

Wiegand SJ, Alexander C, Lindsay RM, DiStefano PS (1991) Axonal transport of ${ }^{125}$ I-labeled neurotrophins in the central nervous system. Soc Neurosci Abstr 17:1121.
Wiegand SJ, Wright P, Alexander C, Pam L, Lindsay RM, Yancopoulos GD, Ip NY (1992) Neurotrophin receptors in the adult rat brain: relative distributions of the low-affinity NGF receptor (LNGFR) and members of the Trk family of tyrosine kinase receptors. Soc Neurosci Abstr 18:949.

Williams LR, Varon S, Peterson GM, Wictorin K, Fischer W, Björklund A, Gage FH (1986) Continuous infusion of nerve growth factor prevents basal forebrain neuronal death after fimbria-fornix transection. Proc Natl Acad Sci USA 83:9231-9235. 